\title{
On the tracks of sandarac, review and chemical analysis
}

\section{Clara Azémard, Matthieu Ménager \& Cathy Vieillescazes}

Environmental Science and Pollution Research

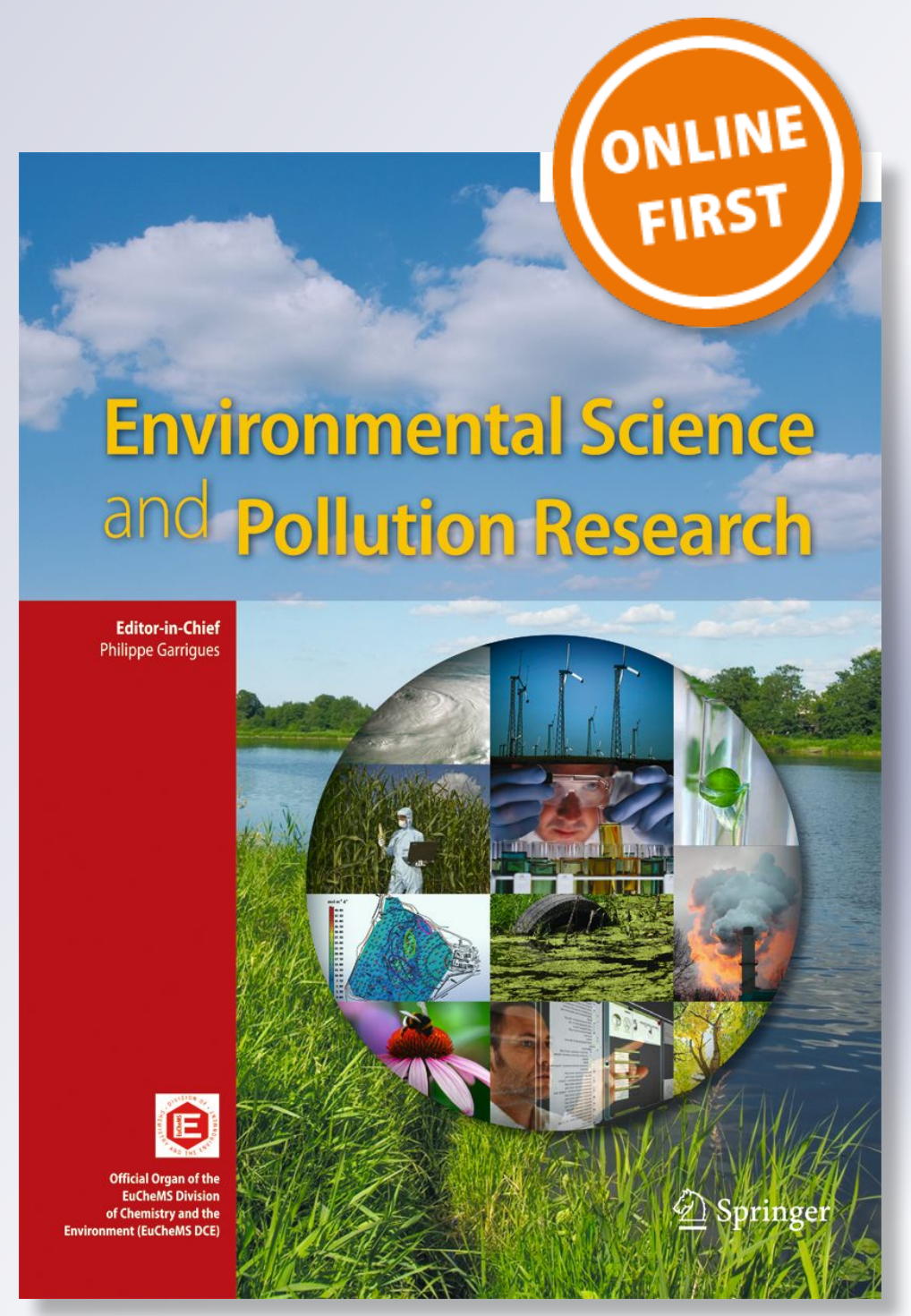


Your article is protected by copyright and all rights are held exclusively by SpringerVerlag GmbH Germany. This e-offprint is for personal use only and shall not be selfarchived in electronic repositories. If you wish to self-archive your article, please use the accepted manuscript version for posting on your own website. You may further deposit the accepted manuscript version in any repository, provided it is only made publicly available 12 months after official publication or later and provided acknowledgement is given to the original source of publication and a link is inserted to the published article on Springer's website. The link must be accompanied by the following text: "The final publication is available at link.springer.com". 


\title{
On the tracks of sandarac, review and chemical analysis
}

\author{
Clara Azémard $^{1} \cdot$ Matthieu Ménager $^{1} \cdot$ Cathy Vieillescazes $^{1}$
}

\begin{abstract}
The sandarac resin (Tetraclinis articulata) has been long used for its properties, mostly as a varnish component. Called juniper resin until the nineteenth century, the real botanical origin of sandarac is still unclear. The first approach to this issue is the review of the evolution of the etymology, terminology, and botanical description of sandarac through time. It seems that sandarac was mainly coming from T. articulata but the use of some juniper resins before the twentieth century is not to be excluded. The second approach is a chemical one; we used gas chromatography coupled to mass spectrometry to characterise the resin. As sandarac was the main component of the famous Italian varnish Vernice liquida, its characterisation is important for old paintings studies. However, although we could hope to differentiate sandarac, Juniperus communis and Juniperus oxycedrus resins by looking at their chemical composition, it appears that these resins are very similar. Besides, we notice a lack of old varnishes containing sandarac which complicates our work.
\end{abstract}

Keywords Sandarac $\cdot$ Juniper $\cdot$ Origin $\cdot$ Botanic $\cdot$ Chemical composition $\cdot$ GC-MS $\cdot$ Vernice liquida

Cathy Vieillescazes

cathy.vieillescazes@univ-avignon.fr

1 Equipe Ingénierie de la Restauration de Patrimoines Naturels et Culturels - IMBE UMR 7263 CNRS - IRD 237 Université d'Avignon - Aix Marseille Université, Avignon, France

\section{Introduction}

The word sandarac can refer either to an arsenic sulphide mineral, the realgar, or to a resin. This resin, as currently marketed, comes from the Tetraclinis articulata (Bouillon 1770; Mills and White 1977; Langenheim 2003). However, it was formerly referred as "Juniper resin". The real origin of this resin is the main interrogation of this paper.

Contrary to Pliny's opinion (Pline 1772), this diterpenic resin has good properties and was used for different purposes: medical cares, varnish component, glue (Wagner and Gautier 1878) or calligraphy. In medicine, sandarac (or juniper resin) was used as a drug for different symptoms: burns, pains, nerves illness, diarrhoeas, intestinal worms, and as a haemostatic drug (Matthioli 1566; Dodoens 1557; Charas 1676; Hill 1751; Bastien 1802; Heuzé 1893). It was indeed usually used for nose bleeding but mostly for haemorrhoids and for regulation of the menstruation (Dodoens 1557; Matthioli 1566; Hill 1751; Bastien 1802; Riddle 1994). It could also be employed in plasters (Charas 1676; Lémery 1732) or mixed with oil to make a cream to prevent hand and feet chap (Dodoens 1557). Although the Europeans stopped using this resin as medicine from the nineteenth century (Wilkes 1827; Huguet 1888), it is still in use in the North of Africa, mostly Morocco (Herlant 1892; Bellakhdar et al. 1991; Bellakhdar 1997). As the realgar was also used as medicine, we can assume from the insistence of various authors on the difference between both sandaracs that some mistakes might have been made, with serious consequences (Dodoens 1557; Matthioli 1566; Felice 1774; Bastien 1802). Powdered sandarac was also used in calligraphy. It was spread (sometimes with a hare foot) to prevent the paper from absorbing ink, improving the quality of writing, hence its designation "writers" varnish" or "sandarac of the writers" by Turquet de Mayerne (Watin 1772; Montabert 1829; Mayerne 1977; Mayer 1998; Perego 2005; Buonanni and Perugini 
2009). It gave back uniformity to scratched paper by filling the gaps and was known as "pounce" in England (Hill 1751; Duplessy 1802; Wilkes 1827). However, sandarac is best known as one of the first varnishes component. That is why the name "vernix" was used in France and trades (Dodoens 1557; Tripier-Deveaux 1845; Herlant 1892). The first evidence in the literature of its use in varnishes dates back the twelfth century (Theophilius 1843). This resin became particularly important during the 15th-16th centuries (Eastlake 2001) with the success of the vernice liquida, a famous Italian oil varnish. Otherwise, sandarac was mostly used as an alcoholic varnish and, afterward, as a spirit varnish despite its coloration with ageing (Watin 1772; Tripier-Deveaux 1845; Hurst 1901). Nowadays, sandarac varnishes are mostly used on wood and no more on paintings (Duplessy 1802).

In term of chemistry, the sandarac resin coming from T. articulata has been studied various times and is composed of approximately $80 \%$ of sandaracopimaric acid, $10 \%$ of callistric acid and $2 \%$ of sandaracinic acid (Thoury 2006). Different phenols (totarol, ferruginol and manool) or various labdanes as agathic acid can also be present (Mills and White 1994; Scalarone, et al. 2003; Perego 2005; Andreotti et al. 2006, Romero-Noguera et al. 2014). Besides, sandarac possesses a polymeric fraction composed of polycommunic acid (Scalarone, et al. 2003; Colombini and Modugno 2009). Many differences in the composition are observed in the literature; the origin of the resin and the time of storage could influence the relative composition (Kononenko et al. 2017). The principal compounds of sandarac have been determined by highperformance liquid chromatography (HPLC) (Sugimoto et al. 2006) but mostly by gas chromatography coupled to mass spectrometry (GC-MS) (van den Berg 2002; Scalarone et al. 2003; Osete-Cortina and Doménech-Carbó 2005; Andreotti et al. 2006; Thoury 2006, Romero-Noguera et al. 2014). Some analysis by fluorimetry (Thoury 2006; Thoury et al. 2007; Nevin et al. 2009), infrared or Raman spectroscopies (Derrick et al. 1999; Daher et al. 2010; Prati et al. 2011; Azémard et al. 2014) also enabled to characterise this resin.

Despite being described in various ancient manuscripts, the origin of sandarac in ancient times is still a source of uncertainty. The evolution of the terminology, and mostly its botanical attribution in the Cupressaceae family through time, is a real issue we try to clarify in the first part of this study. In the second part, we will focus on sandarac chemical composition and its use in old masters varnishes to try to get a better understanding of which trees produced what was then called "Arabian sandarac".

\section{Terminology}

To understand where sandarac resin comes from, it is necessary to find the first times it is mentioned and follow its tracks to nowadays. To do so, it must be considered that sandarac can appear under different names that we will try to explain: sandarac and various derivates (sandarach, sandaracha, sandarus, sandarax, Arabian sandarac), vernix, gum juniper, juniper resin, gum sandarach, sandaracha Arabum. It is particularly interesting to focus on the evolution of the botanical origin given to this resin.

\section{Etymology}

Until at least the sixteenth century, various words were used to

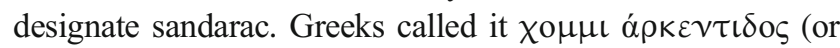

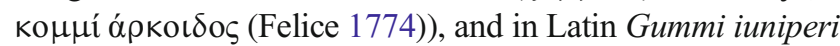
linked it to juniper tree. The Arabians called it sandarax or sandarus and the Barbarian sandaracha whereas French used the term vernix, also employed in the shops according to Dodoens (1557). It was also called El grassa or grasilla by the Spanish and sometimes in Morocco (Merrifield 1849).

Vernix comes from the Greek $\beta \varepsilon \rho \varepsilon \vee\llcorner k \eta$, formerly Electrum referring to the karabe resin. The use of this term is well explained by the fact that amber, karabe and sandarac were considered as very similar by Middle Age authors, as it was mentioned by Avicenna (Persian polymath, 980-1037) and also Serapion the younger (12th-13th c.) (James 1746). Another etymological origin proposed for the term varnish is the Latin word vernum, meaning spring, because it corresponds to the season when the resin is collected (Lémery 1732; Buonanni and Perugini 2009).

Sandarac also comes from the Greek $\sigma \alpha v \delta \alpha \rho \alpha ́ \chi \eta$. This term designates a red arsenic sulphide, the realgar but is apparently also used for the erithace (bee-bread) by Pline the Elder (XI,7) among others (Hill 1751; Felice 1774; Pline 1848). It is explained by its similarity with the glue extracted from the gum of the tree. This glue is said better when strongly red. From this definition, the Arabian may have taken the name ندو , (sandarūs). For them, the issue of differentiation with realgar is inexistent as they name this mineral zarnig. When translated in Latin alphabet, the $[\mathrm{u}]$ became [a] as it often happens according to the author, hence the words sandarax, sandarach and sandarac (Matthioli 1566; James 1746).

To avoid the use of the wrong material (mostly for medical care), an epithet is often added before, Grecian/Arabian, or after, Graecorum/Arabum, the name sandarac (Alexandre 1759; Anonymous 1770; Lemery and Morelot 1807; Wilkes 1827).

\section{Evolution of terminology linked to the botanical attribution}

Though only a few texts mentioning sandarac are found during Middle Age, it seems it already has an important role in art and medicine. As said before, Arabian authors between the 
tenth and the thirteenth centuries mentioned sandarac as medicine and a resin close to amber and karabe (James 1746). The monk Theophilius in his manuscript Diversarum artium schedula (twelfth century) mentions the use of vernix to make varnishes but no botanical origin is given (Theophilius 1843). Jacobus de Tholeto in 1440 is more precise " $S$. 206. To make liquid varnish: Take of the gum of the juniper (sandarac) two parts, and one part of linseed-oil" (Tholeto 1906).

Until the nineteenth century, sandarac has always been described as juniper resin in dictionaries or science books (Dodoens 1557; Matthioli 1566; Pomet 1694; Lémery 1732; James 1746; Hill 1751; Diderot and d'Alembert 1765; Anonymous 1770; Bouillon 1770; Felice 1774; ValmontBomare 1800; Duplessy 1802) as well as books on art techniques (Delormois 1771; Watin 1772; Anonymous 1849a; Matthioli 1906; Mayerne 1977; Anonymous 1999; Buonanni and Perugini 2009). Mostly the English, the Swedish and the Hambourgeois (Pomet 1694) traded sandarac. It could be called Mogador sandarac because the ships bringing the resin to London and Marseille sailed from Morocco, and more particularly Mogador (Essaouira) port (Hurst 1901). It was believed that the best sandarac came from the prickly cedar or cedrus bacciferus (now classified Juniperus oxycedrus) but it is rare so most of the production came in reality from the Juniperus arbour in Africa (Matthioli 1566; Pomet 1694; Lémery 1732; Quincy and Clausier 1749; Hill 1751; Bouillon 1770). In the shops, both resins were likely to be mixed (Hill 1751). Juniperus arbour is in fact the tree form of Juniperus communis that is said to be as tall as $20 \mathrm{ft}$ in some regions. The shrub species of Juniper found in Europe also give sandarac but in so small quantities that they were not exploited (Pomet 1694).

At the end of the eighteenth century, the economic policy of Mohammed III generated the creation of new consulate in North Africa where various botanists travelled or went working. They made inventories of plants and trees found in Algeria and Morocco at that time, enabling a better knowledge of botanical species in that region. Thomas Shaw, a chaplain in Alger, was the first to describe a tree that he named Cypressus fructu quadrivalvi, Equiseti instar articulates (Tilloch 1799). He was followed by P.K.A. Schousboë, general consul of Denmark who lived in Mogador and then Tangier between 1791 and 1832, and who described the same tree and classified it as a thuya. Unluckily, his book on Morocco's flora Iagttagelser over Vextrigeti Marokko was left unfinished and translated in German in 1801 only (Cosson 1881). This thuya (thuja, thuia in some texts) was finally first described and classified by Martin Vahl, a Danish botanish, student of Linné, in Symbolœ botanicœ (Part II, p96, plate XLVIII) after his trip in Tunisia in 1783 (Cosson 1881).

In 1799, Schousboë reported that $J$. communis does not grow in the Atlas mountains and makes the link between sandarac and thuya. The article published in a Danish journal leads to another one, in English this time, in the Philosophical Magazine, under the name "On the real origin of that resin known under the name of sandarac, and that of gum Arabic" (Tilloch 1799). It is noticeable that the statement concerning $J$. communis is not completely true as this species is rare but not absent and that other species of Juniperus such as the J. oxycedrus are also present in this region (Quezel and Gast 1998).

Around the same time, two French botanists, P.M.A. Broussonet, exiled after the revolution then consul in Mogador, and R.L. Desfontaine, member of the science academy and professor at the National Museum of Natural Sciences, reached the same conclusion. They published it in Flora Alantica (1798-1800) and that lead to a pharmaceutical Codex in 1818 on J. communis: "Ex hujus aut congeneris africance cortice,(an potiùs ex thuyà articulatà, testante Broussonnet et memorante Desfontaines?) fluit Sandaracha" (Anonymous 1818).

Thuya genre was already known, sometimes called tree of life, and it may seem strange that nobody found out before that it was the real sandarac tree. However, it must be pointed out that those trees are very similar to a profane and that botanists may not have known the use of the tree.

During the nineteenth century, the identity of sandarac stayed in a state of confusion for part of the scientists and artists. Some authors preferred to put both origins (Lens and Mérat 1831; Planchon 1869; Cameron 1886; Heuzé 1893; Hurst 1901), others Thuya articulata or Callitris articulata (Anonymous 1829; Cuvier 1829; Herlant 1892) and others kept to the Juniperus attribution (mostly in the first part of the nineteenth century) (Duplessy 1802; Malisset 1803; Tingry 1804; Lemery and Morelot 1807; Wilkes 1827; Lens and Mérat 1831). The definition of sandarac in the Dictionnaire des sciences médicales (Medical sciences dictionary) in 1820 (Anonymous 1820) contributed to a polemic and tense exchanges between specialists as it appears in the Journal de pharmacie et des sciences accessoires (Journal of pharmacy and ancillary sciences) in 1820 (Bouillon-Lagrange et al. 1820; d'Hortes 1820). Indeed, J. communis and $J$. oxycedrus are still described as a possible origin of sandarac. Dictionaries are being for many people the reference; it seems more obvious why the resin stayed attributed to Juniperus so long after its new attribution.

At the end of the nineteenth century, M.T. Masters, an English botanist, gives a new botanical name corresponding to the description of Vahl: Tetraclinis articulata. It is the official name nowadays, even if the appellations Callistris quadrivalvis and Thuya articulata are also accepted. From the twentieth century, sandarac is no more described as coming from juniper (Dieterich 1920; de Tarde 1922; Anonymous 1927; Capus 1930; Langenheim 2003).

After the colonisation of North Africa, more information can be found on the exploitation of sandarac. Apparently, the 
forests of Arar (Arabic name) represented a high value and occupy 200,000 ha in Morocco, despite of the forests being removed by fire in the regions where agricultural production was possible (Anonymous 1927). In the first half of the twentieth century, Morocco was the first producer of sandarac followed by Tunisia. They exported the resin to Europe and USA (Capus 1930). Yet, the forests were poorly exploited and without precautions for the tree (Anonymous 1927). Nowadays, sandarac still comes from Morocco but in smaller amount than before due to the creation of turpentine spirit and synthetic varnishes.

We can conclude that the confusion on the sandarac origin comes mostly from a bad botanic knowledge during the Middle Age. Sandarac most probably came from $T$. articulata resin and could have been mixed with $J$. oxycedrus resin, at least for a time. Chemical analysis of old varnish could tell us about the true origin of some sandarac.

\section{Chemistry}

\section{Resin analysis}

\section{Sandarac}

Sandarac resin was analysed using GC-MS(/MS) after methylation and trimethylsilylation (see "Material and methods" section). The analysed fraction of sandarac is composed of various pimaranes and labdanes, as well as some phenols (Table 1). The identification was made thanks to the literature and the study of the path of fragmentation in MS and MS/MS (Azemard et al. 2016). The different derivation procedures lead to strong variations of the relative intensities of various compounds: (i) the cis- and trans-communic acids induces a high signal after the methylation (data not shown), and a weak one after the trimethylsilylation (Fig. 1) and (ii) the 3hydroxy-eperuique acid is absent of methylated samples. Consequently, it can be very interesting to analyse this resin with both methods of derivatisation.

Sandarac varnishes suffer photoageing degradation processes that tend to reduce strongly the proportion of free terpenes. Indeed, the communic acids polymerize forming polycommunic acid. The cross-linking fraction increases with the exposure to light while the amount of communic acids strongly decreases until it is completely transformed (Scalarone et al. 2003, Osete-Cortina and Doménech-Carbó 2005, Colombini and Modugno 2009). Besides, Scalarone et al. observed that the free diterpenes also decrease after photodegradation, probably due to cross-linking or/and the formation of diterpenes, undetectable by GC-MS (2003). This decrease of identifiable molecules makes even harder the identification of the resins after ageing.
Juniper

Some resin was collected on J. communis and J. oxycedrus in the south of France to be compared by GC-MS with T. articulata resin. Mills and White already pointed out that polycommunic acid is present in Juniperus resin (Mills and White 1994). The chromatographs clearly show a strong similarity between sandarac and $J$. oxycedrus resin: the major peaks are in this order: 3-hydroxy-eperuic, hydroxysandaracopimaric and sandaracopimaric acids. We can also observed various other acids and two phenols: sugiol and ferruginal (Fig. 1). The resin coming from J. communis shows slight differences with a much smaller peak of hydroxysandaracopimaric acid and an intense peak of sugiol that may enable to differentiate this resin from the two others. However, as said before, differences can also be observed between trees of the same species but with different environment. Kononenko et al. (2017) showed a qualitative similarity between sandarac from different suppliers but quantitative differences. Therefore, the identification of $J$. communis must be done with precautions. Besides, as the three species share the same composition, aged resins are most probably also very similar. The identification of the species used for ancient sandarac remains complex even with analytical techniques.

\section{Sandarac varnishes}

\section{Old recipes}

Sandarac resin has been used in numerous recipes of varnishes since Middle Age. Those recipes can be divided in two groups: alcoholic varnishes and oil varnishes. Sandarac is well soluble in alcohol and was often used to make a bright, transparent varnish. Many recipes can be found for paintings and wood (Bouillon 1770; Watin 1772; Tingry 1804; Montabert 1829; Anonymous 1849a; Armenini 1977; Buonanni and Perugini 2009) (Supplementary information). Sandarac is the basis of many alcoholic varnishes, but it tends to give brittleness to the varnish. To avoid this defect, it is often mixed with elemi, gum anima or shellac (Duplessy 1802; Tingry 1804; Montabert 1829; Tripier-Deveaux 1845; Buonanni and Perugini 2009). Alcoholic varnishes are no longer used for paintings as spirit varnishes made with turpentine spirit are preferred.

Oil varnishes are mentioned from the eigth to the ninth century in Lucques' manuscript, but their existence is most probably older (Perego 2005). The choice of the oil is of first importance when making varnishes. The oil has to be colourless, siccative and odourless. Although the oil varnishes are more flexible and less brittle than alcoholic varnishes, they need a longer time to dry and are more coloured (McIntosh 1908; Perego 2005). Sandarac is hardly soluble in most oils; 
Table 1 Principal molecules identified in fresh sandarac resin after trimethylsilylation $\left(t_{R}\right.$ time of retention, $M w$ molecular weight)

\begin{tabular}{llll}
\hline$t_{\mathrm{R}}(\min )$ & Mw & Other peaks & Attribution \\
\hline 22.65 & 275 & $257,187,177,122,95,79$ & Manoyl oxide \\
25.98 & 358 & $343,301,273,261,247$ & Ferruginol \\
26.44 & 374 & $359,256,241,187,161,159,133,121,73$ & Cis-communic acid \\
26.68 & 374 & $359,256,241,200,161,148,134,119,105,73$ & Trans-communic acid \\
27.11 & 374 & $359,346,257,241,145,121,105$ & Sandaracopimaric acid \\
27.32 & 374 & $359,256,241,227$ & Isopimaric acid \\
31.06 & 372 & $357,315,275,235$ & Sugiol \\
31.35 & 466 & $451,376,348,258,161,121,73$ & 3-hydroxy-eperuic acid \\
32.35 & 464 & $449,374,359,269,256,241,189,147,105,73$ & Hydroxy-sandaracopimaric \\
& & & acid \\
33.29 & 480 & $465,447,362,347,272,255,239,175,161,121,73$ & Pinifolic acid \\
33.42 & 478 & $463,360,346,307,271,253,227,189,121,73$ & Isoagathic acid \\
35.23 & 478 & $463,373,360,346,307,271,253,229,213,189,121,73$ & Agathic acid \\
\hline
\end{tabular}

some authors even consider it is only entirely soluble in aspic oil (oil of spike lavender) (Charas 1676; Pomet 1694). However, according to the old recipes found in the literature (see Supplementary material), this resin was often used mixed with linseed oil, to make a famous varnish that the Italian called vernice liquida. This varnish, considered for a long time as the best varnish for paintings, was mentioned by Leonardo da Vinci (da Vinci and Chastel 2003) and may have been the

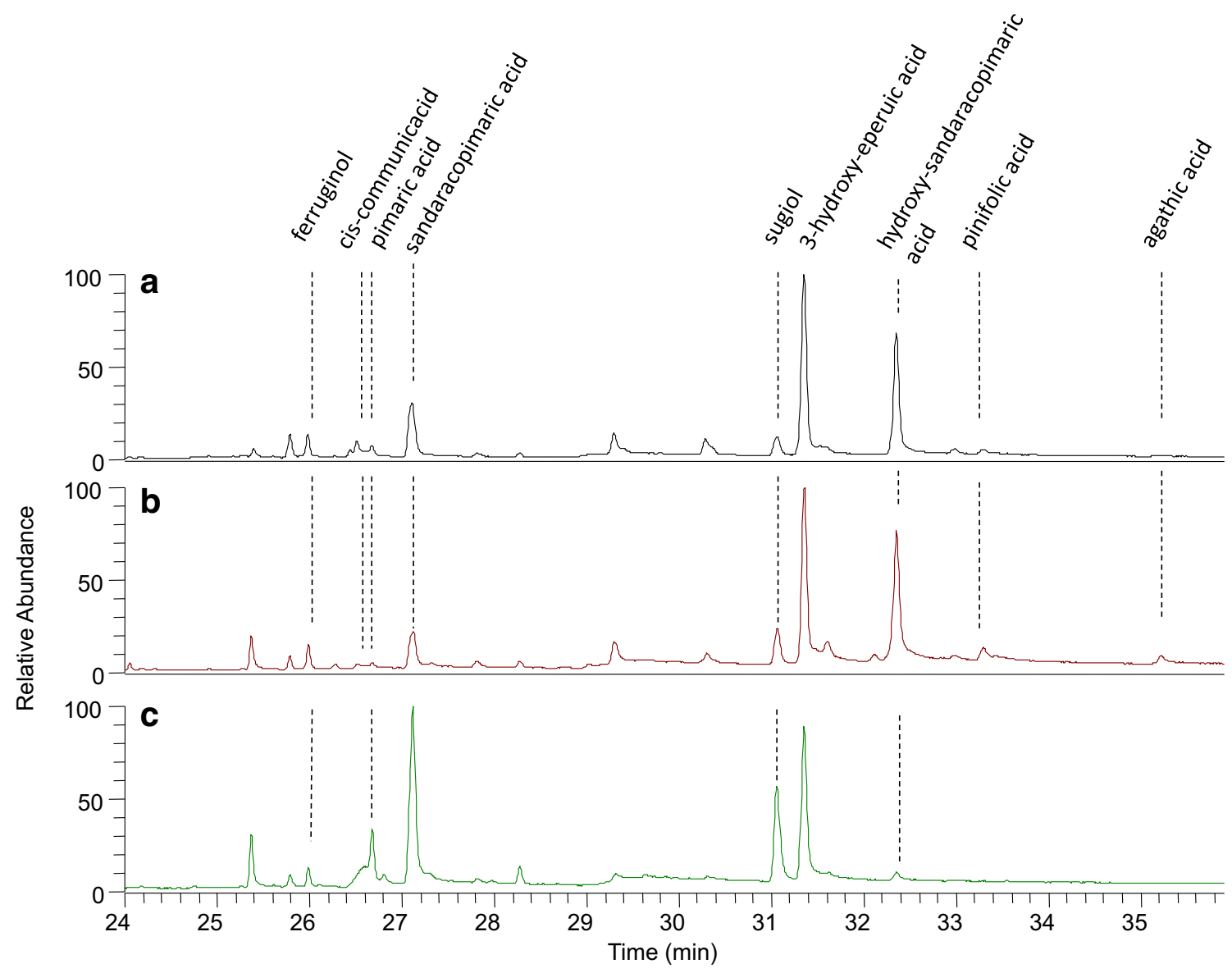

Fig. 1 Chromatograms of a) Tetraclinis articulata, b) Juniperus oxycedrus, and c) Juniperus communis resins after trimethylsilylation 
one used for Byzantine icons (Vieillescazes et al. 2005). The ordinary recipe of vernice liquida consists in two or three parts of linseed oil (sometimes nut oil) for one part of sandarac. This varnish is frequently mentioned and many recipes of vernice liquida and other oil varnishes made with sandarac can be found in old art manuscripts from the twelfth to the nineteenth century (Borghini 1730; Delormois 1771; Theophilius 1843; Anonymous 1849b, c; Sabin 1906; Eastlake 2001;Buonanni and Perugini 2009) (Supplementary material). Merrifield in her book reuniting various manuscripts reviews some of the different recipes and denominations of vernice liquida (chap.VI) (1849). The oldest is the Formula of Theophilus (Theophilius 1843): (i) Put linseed oil and sandarac finely ground in a container and (ii) heat without boiling until one-third is evaporated. Another more detailed recipe with two thirds of oil and one third of resin (in weight) is proposed: (i) Heat separately the oil and the resin. The resin is put in a close pot, with a second pot with its bottom perforated embed on the first one, the whole thing with stirring; (ii) when the resin is melted, add the oil; (iii) heat the mixture, but do not let it boil and (iv) remove from the heat and let cool down.

This system with two pots, one on the top of the other, is also used by Jehan le Begue in his manuscript (1431, recipe $31)$ to make an « aromatic glassa » varnish (probably copal or amber) (Le Bègue 1849). Indeed, as the sandarac is hardly soluble, the artists probably used various techniques to enhance solubility. Some incorporate the powdered resin to boiling hot oil and continue the ebullition for a moment (Anonymous 1849b, c; Eastlake 2001); others heat separately the resin and the oil and when the resin is almost completely melted and fluid, the oil is incorporated (Eastlake 2001; Sabin 1906). Another technique is to use additives such as turpentine spirit, mordant, and other resins (Merrifield 1849; Buonanni and Perugini 2009). According Fioravanti, if the oil is not cooked, the resin shall burn. Besides, he indicates to let the oil cool down before adding the resin (Buonanni and Perugini 2009). We tried several times to make vernice liquida from linseed oil and sandarac only; the dissolution was scarce and the final solution yellow-brownish. Besides, precautions must be taken when making this varnish; indeed, the oil tends to ignite when the temperature is too high. It is probable that the recipes are lacking some precision (temperature) on purpose to keep the secret of the masters, or that they were made only as to remember the principal components but that in reality additives were used, enabling the dissolution. The violinmaker Koen Padding had apparently sold an oil varnish on "Magister Varnish Products" composed of oil and sandarac and called Vernice liquida commune. Unfortunately, he died in 2012 leaving no recipe for this varnish, whose analyses done by FTIR only gave a $20 \%$ in ratio of resin, probably sandarac but possibly mixed with other resins according to Helen Michetschläger (Michetschläger 2015; Lynch 2016).
Analysis of varnish samples

With the apparition of turpentine spirit-based varnishes at the end of the eighteenth century, and later of dammar resin, an interesting alternative to mastic, the sandarac varnishes lost their popularity. They are now only used for wood (particularly lute-making). However, looking at the numerous recipes involving sandarac, it seems legitimate to find some sandarac varnishes on ancient artworks, wooden furniture or instruments. In 4 years, we had the chance to analyse 19 painting varnishes and two wood varnishes (see Supplementary material). We hoped to find sandarac in at least one of the older samples but even the wood varnishes did not reveal any trace of this resin (Azémard 2014). Looking at the literature, sandarac is in fact only rarely found on artworks. A few Cupressaceae resin was found on National Gallery's paintings. It is the case of the study of a panel by Carlo Crivelli and of a Virgin and Child (Albrecht Durer?). However, the authors precise it is not possible to tell if Tetraclinis or Juniperus resin was used (Dunkerton and White 2000; Ackroyd et al. 2000). Sandarac was also identified on an Irish Harp dating around 1825 (Mills and White 1977).

The major reason of the lack of old samples with sandarac is most probably the campaign of cleaning of paintings that occurred during the eighteenth and nineteenth centuries. Old varnishes were removed and new ones, without sandarac, applied. Besides, the polymeric fraction forming during ageing is harder to remove.

Furthermore, the ancient recipes may not have been always followed. Indeed, as shown by Vieillescazes et al. (2005), it seems for example that the Monks of the Mount Athos preferred to use colophony, a resin easily soluble in oil resin than sandarac to varnish their Byzantine icons in contradiction with Dionysios of Fourna writings. It is also clear that the resin sold under the name of sandarac was not always sandarac. As said before, resins from different trees (thuya and junipers) were mixed, and Tingry warns against forgeries in the shops that may have been common at that time (1804).

\section{Conclusion}

The sandarac resin was apparently produced mostly by Tetraclinis articulata tree, growing in the North of Africa. Juniperus oxycedrus resin might have also been used and sold as sandarac. The name juniper gum seems to come only from a lack of botanical knowledge and the confusion between close genres of the Cupressaceae family. Even chemically, Tetraclinis and Juniperus are really similar; the possibility of discriminating those resins in their fresh and aged states is reduced. However, the principal issue is to find old sandarac varnishes. Indeed, most of them have been removed long ago, 
and the others are much degraded or are hardly removable, which complicates the identification.

\section{Material and methods}

Sandarac resin was purchased at EMIGA S.A. Both juniper resins were collected on the summer 2012 in the south of France: Juniperus communis resin was collected in Aulusles-Bains (Ariège) and Juniperus oxycedrus in Tautavel (Pyrénées Orientales). All samples were trimethylsilylated before injection, with BSTFA $+1 \% \mathrm{TMCS}\left(30 \mathrm{~min}, 70^{\circ} \mathrm{C}\right)$ or methylated with TMSH $\left(30 \mathrm{~min}, 70{ }^{\circ} \mathrm{C}\right)$. For the artificial ageing, the resins were dissolved in ethanol and spread on a microscope slide then aged under artificial sunlight (SUNTEST CPS+, Atlas) during at least $300 \mathrm{~h}$ under the following conditions: $35^{\circ} \mathrm{C}$ and $765 \mathrm{~W} / \mathrm{m}^{2}$.

The analyses were performed on a Thermo Fisher Focus GC coupled to an ion trap ITQ 700 mass spectrometer. We used Excalibur software to treat our data. The analyses were carried out under a helium flux of $1.2 \mathrm{ml} / \mathrm{min}$. The injector and the ion source temperatures were set at $250^{\circ} \mathrm{C}$ and the transfer line at $300{ }^{\circ} \mathrm{C}$. All analyses were done with two different sets of electron energy/lens tension parameters: (i) $70 \mathrm{eV} / 10 \mathrm{~V}$, the usual ones, also used for the MS/MS experiments and (ii) $17 \mathrm{eV} / 50 \mathrm{~V}$, in order to always get the mass weight and have a better vision of some fragmentations. For both parameters, the emission current was $250 \mu \mathrm{A}$. MS/MS experiments were carried out as complementary analyses on the major peaks of the different molecules mass spectra.

Acknowledgements The authors would like to express their gratitude to all the conservators-restorers who collected varnishes samples, especially Thierry Martel for trying to make vernice liquida in his workshop. Many thanks to Caroline Hudry who helped collecting Juniperus oxycedrus resin.

\section{References}

d'Hortes H (1820) Quelques réflexions sur l'article Résines du Dictionnaire des sciences médicales. J Pharm Sci Accessoires 6(11):537-538

Ackroyd P, Foister S, Spring M, White R, Billinge R (2000) A Virgin and Child from the Workshop of Albrecht Dürer? In: Ashok Roy and Anton van Dyck (eds) National Gallery Technical Bulletin 21. National Gallery Technical Bulletin, pp 28-42

Alexandre N (1759) Dictionnaire botanique et pharmaceutique contenant les principales propriétés des Mineraux, des Végétaux et des Animaux. Paris

Andreotti A, Bonaduce I, Colombini M-P, Modugno F, Ribechini E, Gautier G (2006) Combined GC/MS analytical procedure for the characterization of glycerolipid, waxy, resinous, and proteinaceous materials in a unique paint microsample. Anal Chem 78(13):4490-4500

Anonymous (1770) Le grand vocabulaire françois. Panckoucke

Anonymous (1818) Codex medicamentarius sive Pharmacopoea gallica jussu regis optimi et ex mandato summi rerum internarum regni administri. Facultate Medica Parisiensi, Apud Hacquart

Anonymous (1820) Dictionnaire des sciences médicales, Panckoucke
Anonymous (1829) Dictionnaire des sciences naturelles, dans lequel on traite méthodiquement des différens êtres de la nature, considérés soit en eux-mêmes d'après l'état actuel de nos connoissances, soit relativement a l'utilitè qu'en peuvent retirer la médecine, l'agriculture, le commerce et les artes. Suivi d'une biographie des plus célèbres naturalistes ... par plusieurs professeurs du Jardin du Roi, et des principales écoles de Paris. First volume. F. G. Levrault

Anonymous (1849a) Paduan Manuscript ; Entitled « Ricette per Far Ogni Sorte Di Colori »,etc. In: Merrifield MP (ed) Medieval and Renaissance treatises on the arts of painting: original texts with English translations. J Murray, London, pp 643-718

Anonymous (1849b) Bolognese manuscript entitled « Segreti per Colori ». In: Merrifield MP (ed) Medieval and Renaissance treatises on the arts of painting: original texts with English translations. J. Murray, London, pp 325-602

Anonymous (1849c) Marciana Manuscript Entitled "secreti Diversi". In: Merrifield MP (ed) Medieval and Renaissance treatises on the arts of painting: Original Texts with English Translations. J. Murray, London, pp 602-642

Anonymous (1927) Les Forêts Du Maroc. Rev Bot Appl Agric Colon 65: 588-592

Anonymous (1999) Varnishes and very curious secrets: Cremona, 1747: the manuscript 4 (H 113) of the Biblioteca Trivulziana in Milan. Cremonabooks, Cremona

Armenini G B (1977) On the true precepts of the art of painting. Ayer Publishing

Azémard C (2014) Photodégradation des resins naturelles: application au domaine artistique, Université d'Avignon

Azémard C, Vieillescazes C, Ménager M (2014) Effect of Photodegradation on the identification of natural varnishes by FTIR spectroscopy. Microchem J 112:137-149

Azemard C, Menager M, Vieillescazes C (2016) Analysis of diterpenic compounds by GC-MS/MS: contribution to the identification of main conifer resins. Anal Bioanal Chem 408(24):6599-6612

Bastien J-F (1802) Dictionnaire botanique et pharmaceutique... Bastien JF, Paris

Bellakhdar J (1997) La pharmacopée marocaine traditionnelle: médecine arabe ancienne et savoirs populaires. Ibis Press, Paris

Bellakhdar J, Claisse R, Fleurentin J, Younos C (1991) Repertory of standard herbal drugs in the Moroccan pharmacopoea. J Ethnopharmacol 35:123-143

van dan Berg JDC (2002) Analytical chemical studies on traditional linseed oil paints. MOLART, Amsterdam

Borghini R. (1730) Il riposo di Raffaello Borghini. Fondo Cicognara (Biblioteca apostolica vaticana). Nestenus M, Moücke F

Bouillon A (1770) Dictionnaire portatif de commerce, contenant la connoissance des marchandises de tous les pays, ou les principaux \& nouveaux articles, concernans le commerce \& l'economie: les arts, les manufactures, les fabriques, la minéralogie, les drogues, les plantes, les pierres précieuses, \&c. ..., ... vol.4. Société typographique, Liège

Bouillon-Lagrange P J B, Cadet C L, Planche L A, Boulay P F G, Boudet J P, Virey J J, Pelletier J, Vogel A (1820) J Pharm Sci Accessoires, vol. 6. L. Colas Fils, Paris

Buonanni F, Perugini F (2009) Techniques of Chinese lacquer: the classic eighteenth-century treastise on Asian varnish. Getty Publications, Los Angeles

Cameron J (1886) Oils and varnishes. J and A Churchill, London

Capus G (1930) Les Produits Coloniaux D’origine Végétale. Librairie Larose, Paris

Charas M (1676) Pharmacopée Royale Galénique et Chymyque. D'Houry L., Paris

Colombini MP, Modugno F (2009) Organic mass spectrometry in art and archaeology. John Wiley \& Sons, Chichester

Cosson E (1881) Compendium Florae Atlanticae : Seu Expositio Methodica Plantarum Omnium in Algeria, vol 1. Masson G, Paris 
Cuvier (1829) Dictionnaire des sciences naturelles. Le Normant, Paris

Daher C, Paris C, Le Hô AS, Bellot-Gurlet L, Échard JP (2010) A joint use of Raman and infrared spectroscopies for the identification of natural organic media used in ancient varnishes. J Raman Spectrosc 41(11):1494-1499

Delormois (1771) vernisseur parfait: ou, Manuel du vernisseur. Jombert C A, Paris

Derrick MR, Stulik D, Landry JM (1999) Infrared spectroscopy in conservation science. The Getty Conservation Institute, Los Angeles

Diderot D, d'Alembert JLR (1765) L'encyclopédie, Tome Quatorzième. L'Encyclopédie. S. Faulche \& Co, NeufChastel

Dieterich K (1920) The analysis of resins, balsams, and gum resins. Scott, London

Dodoens R (1557) Histoire des plantes en laquelle est contenue la description entiere des herbes... non seulement de celles qui croissent en ce païs, mais aussi des autres estrangères qui viennent en usage de médecine. Charles L'Escluse.Newton N., London

Dunkerton J, White R (2000) The discovery and Iientification of an original varnish on a panel by Carlo Criverlli. In: Roy A, Kirby J (eds) National Gallery Technical Bulletin, vol 21. Nat Gallery Publ, London

Duplessy F S (1802) Des végétaux résineux, tant indigenes qu'exotiques; ou description complete des arbres, arbrisseaux, arbustes et plantes qui produisent des resines; avec les procedes pour les extraire; l'indication detaillee de leurs proprietes et usages dans la medecine, la pharmacie, l'art veterinaire, la peinture, les vernis, la teinture, la parfumerie, l'economie domestique, et en general dans tous les arts utiles et agreables; on y joint la synonymie; les noms vulgaires en sept langues, la culture, etc.; et un memoire de J. Nauche ... sur la maniere dont les substances resineuses agissent dans l'economie animale ..., vol.1. Delalain, Paris

Eastlake CL (2001) Methods and materials of painting of the great schools and masters. Courier Dover Publications, New-York

de Felice F B (1774) Encyclopédie ou Dictionnaire universel raisonné des connoissances humaines. Yverdon

Herlant A (1892) Étude Descriptive Des Médicaments Naturels D’origine Végétale, .... Lamertin H., Bruxelles

Heuzé G (1893) Les Plantes Industrielles. Plantes Narcotiques, Saccharifères, Pseudo-Alimentaires, Lactifères, Résineuses, Astringentes, Médicinales et Funéraires. Hachette, Paris

Hill J (1751) A History of the Materia Medica: Containing Descriptions of All the Substances Used in Medicine... Longman, London

Huguet R (1888) Traité de Pharmacie Théorique et Pratique. Doin O, Paris

Hurst GH (1901) Dictionary of chemicals and raw products used in the manufacture of paints, colours, varnishes and allied preparations. Greenwood and co., London

James RJ (1746) Dictionnaire universel de medecine, de chirurgie, de chymie, de botanique, d'anatomie, de pharmacie, d'histoire naturelle, \&c, vol 1. Busson J, Paris

Kononenko I, de Viguerie L, Rochut S, Walter P (2017) Qualitative and quantitative studies of chemical composition of sandarac resin by GC-MS. Environ Sci Pollut Res Int 24(3):2160-2165

Langenheim JH (2003) Plant resins: chemistry, evolution, ecology, and ethnobotany. Timber Press, Portland

Le Bègue J (1849) Manuscrit de Jehan Le Bègue. In: Merrifield MP (ed) Medieval and Renaissance treatises on the arts of painting: original texts with English translations. J. Murray, London, pp 1-111

Lémery N (1732) Traité universel des drogues simples, mises en ordre alphabétique: ouvrage dépendant de la pharmacopée universelle. D'Houry L., Paris

Lemery N, Morelot S (1807) Nouveau dictionnaire général des drogues simples et composées. Rémont, Paris

de Lens AJ, Mérat FV (1831) Dictionnaire universel de matière médicale et de thérapeutique générale: contenant l'indication, la description et l'emploi de tous les médicaments connus dans les diverses parties du globe. Baillière JB, Paris
Lynch P (2016) Magister varnish oil resin ration. Maestronet Forums. http://www.maestronet.com/forum/index.php?/topic/333798magister-varnish-oil-resin-ratio/page-6, accessed July 29, 2016

Malisset JB A (1803) La boussole des speculateurs, contenant un traité complet et méthodique de la science du commerce ... Obré, Paris

Matthioli PA (1566) Les commentaires sur les six livres des Simples de Pedacius Dioscoride Anazarbeen. Cotier, Lyon

Matthioli PA (1906) In: Sabin AH (ed) The industrial and artistic technology of paint and varnish. John Wiley \& Sons, New-York, p 19

Mayer L (1998) Traditional artists' varnishes. In: Samet W (ed) Painting conservation catalog, varnishes and surface coatings, vol 1. Paintings specialities Group of the AIC, Washington, pp 21-34

de Mayerne TT (1977) In: Versini C, Faidutti M (eds) Pictoria, sculptoria et quae subalternarum artium: 1620 le manuscrit. Audin, Lyon

McIntosh J G (1908) The Manufacture of Varnishes and Kindred Industries Based on and Including the "Drying Oils and Varnishes.” D. Van Nostrand Co.; [etc.]. http://archive.org/details/ manufacturevarn00mcingoog, accessed August 24, 2014

Merrifield MP (1849) Medieval and Renaissance treatises on the arts of painting: original texts with English translations. J. Murray, London

Michetschläger H (2015) Violin varnish: notes and articles from the workshop of Koen padding. Sale, Doratura, UK

Mills JS, White R (1977) Natural resins of art and archaeology their sources, chemistry, and identification. Stud Conserv 22:12-31

Mills J S, White R (1994) Organic chemistry of museum objects. 2nd Ed. B.H. Series. Conservation and Museology. Oxford

Montabert J N P de (1829) Traité complet de la peinture. Delion JF, Paris

Nevin A, Echard JP, Thoury M, Comelli D, Valentini G, Cubeddu R (2009) Excitation emission and time-resolved fluorescence spectroscopy of selected varnishes used in historical musical instruments. Talanta 80(1):286-293

Osete-Cortina L, Doménech-Carbó MT (2005) Analytical characterization of diterpenoid resins present in pictorial varnishes using pyrolysis-gas chromatography-mass spectrometry with on line trimethylsilylation. J Chromato A 1065(2):265-278

Perego F (2005) Dictionnaire des matériaux du peintre. Belin, Paris

Planchon G (1869) Histoire naturelle des drogues simples: ou, Cours d'histoire naturelle professé à l'École de pharmacie de Paris. J.-B. Baillière et fils, Paris

Pline l'Ancient (1772) In: Desaint (ed) Livre XIII: Qui traite des parfums $\&$ des arbres d'outre-mer. Histoire naturelle, Paris

Pline l'Ancient (1848) In: Dubochet JJ, Le Chevalier et Comp (eds) Livre XI, Des insectes. Des parties du corps. Historia naturelle de Pline, Paris

Pomet P (1694) Histoire générale des drogues: traitant des plantes, des animaux, \& des mineraux : ouvrage enrichy de plus de quatre cent figures en taille-douce ... chez Jean-Baptiste Loyson, \& Auguste Pillon ... ; et au Palais, Ducastin, Paris

Prati S, Sciutto G, Mazzeo R, Torri C, Fabbri D (2011) Application of ATR-far-infrared spectroscopy to the analysis of natural resins. Anal Bioanal Chem 399(9):3081-3091

Quezel P, Gast M (1998) Genévrier. In: Camps G (ed.) Encyclopédie berbère. Peeters, pp. 3016-3023. http://encyclopedieberbere. revues.org/1863, accessed September 14, 2012

Quincy J, Clausier JL (1749) Pharmacopée universelle. D’Houry, Paris

Riddle JM (1994) Contraception and abortion from the ancient world to the renaissance. Harvard University Press, Cambridge

Romero-Noguera J, Martín-Sánchez I, Doménech-Carbó MT, OseteCortina L, López-Miras MM, Bolívar-Galiano F (2014) Analytical characterisation of the biodeterioration of diterpenoid labdanic varnishes used in pictorial techniques: sandarac and Manila copal. Int Biodeterior Biodegrad 90:99-105

Sabin AH (1906) The industrial and artistic technology of paint and varnish. John Wiley \& Sons, New-York

Scalarone D, Lazzari M, Chiantore O (2003) Ageing behaviour and analytical pyrolysis characterisation of diterpenic resins used as art 
materials: Manila copal and sandarac. J Anal Appl Pyrolysis 68-69: $115-136$

Sugimoto N, Kuroyanagi M, Kato T et al (2006) Identification of the main constituents in sandarac resin, a natural gum base. Shokuhin Eiseigaku Zasshi J Food Hyg Soc Jpn 47(2):76-79

de Tarde A (1922) Le Maroc Économique et Financier. France-Maroc 63. http://gallica.bnf.fr/ark:/12148/bpt6k61202228, accessed March 9, 2016

Theophilius (1843) Theophili, presbyteri et monachi, Libri III, seu Diversarum artium schedula. Opera et studio Caroli de L'Escalopier. JA, Toulouse

de Tholeto J (1906) Formulae from Jacobus de Tholeto, 1440. In: Sabin $\mathrm{AH}$ (ed) The industrial and artistic technology of paint and varnish. John Wiley \& Sons, New York

Thoury M (2006) Identification Non-Destructive Des Vernis Des Oeuvres D'art Par Fluorescence UV. Université Pierre et Marie Curie, Paris VI

Thoury M, Elias M, Frigerio JM, Barthou C (2007) Nondestructive varnish identification by ultraviolet fluorescence spectroscopy. Appl Spectrosc 61(12):1275-1282

Tilloch A (1799) Philosophical Magazine. Taylor \& Francis, London

Tingry P F (1804) The painter and varnisher's guide: or, A treatise, both in theory and practice, on the art of making and applying varnishes, on the different kinds of painting; and on the method of preparing colours both simple and compound ... Kearsley G, London
Tripier-Deveaux A M (1845) Traité théorique et pratique sur l'art de faire les vernis: suivi de deux mémoires, l'un sur les dangers qui menacent les peintures vernies d'extérieurs, l'autre sur les précautions à prendre pour assurer aux revernissages la même durée qu'aux vernissages faits sur les peintures fraîches. Mathias L, Paris

Valmont-Bomare J C (1800) Dictionnaire raisonné, universel d'histoire naturelle: Contenant l'histoire des animaux, des végétaux et des minéraux, et celle des corps célestes, des météores, et des autres principaux phénomenes de la nature; avec l'histoire des trois règnes, et ... une table concordante des noms latins, ... Chez Bruyset ainé et ce, Lyon

Vieillescazes C, Archier P, Pistre MS (2005) Study of post-byzantine icon varnishes by chromatographic and spectroscopic methods. Stud Conserv 50(1):37-44

da Vinci L, Chastel A (2003) Traité de la peinture. Calmann-Lévy, Paris von Wagner J R, Gautier L (1878) Nouveau Traité de Chimie Industrielle : À L'usage Des Chimistes, Des Ingénieurs, Des Industries...., vol.2. Savy F

Watin (1772) de faire et d'employer le vernis ou l'art du vernisseur. Quillau, Paris

Wilkes J (1827) Encyclopaedia Londinensis, Or, Universal Dictionary of Arts, Sciences, and Literature, vol XXII. Jones G, -London 